Zabytkoznawstwo i Konserwatorstwo XLIII, Toruń 2012

\author{
Maria Rdesińska*, Paulina Szmaglińska*** \\ Alina Tomaszewska-Szewczyk* \\ * Wydział Sztuk Pięknych, Instytut Zabytkoznawstwa i Konserwatorstwa \\ * Wydział Nauk Historycznych, Instytut Archeologii
}

\title{
Znaki pielgrzymie. Przyczynek z zakresu kultury materialnej i konserwacji
}

T ednym z namacalnych śladów religijności średniowiecznej są znaki pielgrzymie - wytwory uwarunkowane religia i kulturą, których technika wytwarzania ukierunkowana była na produkcję masowa. Odnajdowane są one w stanie wymagajacym interwencji konserwatorskiej, prowadzącej do przywrócenia im wartości estetycznych i zabezpieczenia przed procesami korozyjnymi. Przedmiotem opracowania są znaki pielgrzymie wydobyte podczas badań archeologicznych w Gdańsku na Wyspie Spichrzów przy ul. Pszennej w 2008 roku¹. Odbywanie podróży do miejsc świętych należy do tego rodzaju uniwersalnych praktyk religijnych, które towarzyszą człowiekowi od dawien dawna, niezależne od wyznania czy miejsca. W kręgu kultury basenu Morza Śródziemnego ma ono długa tradycję, a w religii chrześcijańskiej było praktykowane niemal od chwili jej powstania. Szczególne miejsce zajmowały w niej zawsze podróże do Ziemi Świętej, do miejsc związanych z życiem i śmiercia Chrystusa. Szybko równie niezwykła popularność zyskały też szlaki apostolskie do Rzymu i Composteli oraz liczne pomniejsze miejsca pielgrzymkowe 2 .

\footnotetext{
1 Badania archeologiczne prowadziła Pracownia Archeologiczno-Konserwatorska Marii Karoliny Kocińskiej.

2 A. Witkowska OSU, Peregrinatio religiosa w średnioniecznej Europie, [w:] Peregrinationes. Pielgraymki w kulturze dawnej Europy, red. H. Manikowska, H. Zaremska, Warszawa 1995, s. 9.
} 
Nadrzędnym celem pielgrzymowania było przede wszystkim utorowanie sobie drogi do zbawienia. Istniało jednak wiele dodatkowych powodów, dla których wyruszano w taką niełatwą w końcu podróż. Należały do nich, m.in. wypełnienie przysiag złożonych $\mathrm{w}$ obliczu choroby lub niebezpieczeństwa, uzyskanie przebaczenia za grzechy, wybłaganie łask u wybranego świętego, czy podziękowanie za ich dostąpienie. Przyczyną mogła być również pokuta lub po prostu konieczność czasowego opuszczenia miejsca zamieszkania.

U źródeł praktyk pielgrzymkowych leżało przekonanie o skuteczności relikwii i cudownych obrazów, a także wadze bezpośredniego kontaktu z miejscem kultu. Z czasem do tych religijnych motywów dołączyły się też inne, takie jak ciekawość świata, potrzeba spotkania z innymi ludźmi, doświadczenia innego życia niż to znane na co dzień. Pielgrzymki zaczęly stawać się nie tyko ćwiczeniem w pobożności, ale również czymś w rodzaju okazji towarzyskich, łącząc z nią elementy czegoś, co dziś - w dużym uproszczeniu - moglibyśmy określić mianem turystyki ${ }^{3}$.

Tak jak wielu podróżników i pielgrzymów dzisiaj, także średniowieczni mieli potrzebę przywiezienia ze sobą namacalnego dowodu odbytej podróży. Z Ziemi Świętej przywożono na przykład flasze wypełnione wodą z Jordanu, czy fragmenty Złotej Bramy, przez którą do Jerozolimy w niedzielę palmowa wjechał Chrystus ${ }^{4}$. Zwyczaj był tak powszechny, że bardzo szybko okazał się poważnym problemem. Miejsca pielgrzymek niszczały pod wpływem tych praktyk tak bardzo, że zakazywano ich - nawet pod groźba ekskomuniki. Z problemem tym zaczęto sobie również radzić poprzez wytwarzanie i sprzedaż tanich pamiątek, takich jak: pudełka z ziemią, z której Bóg miał ulepić postać Adama, czy modele i malunki różnych miejsc świętych. Ampułki z woda z Jordanu i innymi płynami o cudownych właściwościach były sprzedawane w Ziemi Świętej już od początku VI wieku, na Zachodzie jednak podobne flakoniki oraz inne metalowe pamiątki na skalę masową zaczęto produkować $\mathrm{w}$ drugiej połowie XII wieku, kiedy to nastapił znaczny rozwój ruchu pielgrzymkowego do europejskich miejsc

3 B. Spencer, Pilgrim Souvenirs and Secular Badges. Medieval Finds from Excavations in London, London 1998, s. 3.

4 Ibidem, s. 2-4. 
kultu. Od tego momentu aż po XVI wiek pamiątki takie, zwane znakami, stały się stałym elementem wyposażenia pielgrzyma 5 .

Znaki były przez pielgrzymów wyraźnie eksponowane - przyczepiano je najczęściej do nakrycia głowy, torby podróżnej lub płaszcza czy peleryny, stąd też często zaopatrywano je w uchwyty, klamry lub uszka, dzięki którym znak można było przytwierdzić. Kształt znaków, przedstawienia umieszczane na nich oraz ich układ były charakterystyczne dla poszczególnych centrów pielgrzymkowych, przy czym w wielu popularnie uczęszczanych miejscach produkowano więcej niż jeden ich typ. Przedstawiały one zazwyczaj wizerunek świętego, którego w danym miejscu otaczano szczególnym kultem, czczone w danym miejscu relikwie lub symbole chrześcijańskie. Czasami opatrywano je inskrypcjami wskazującymi na miejsce pochodzenia, chociaż praktyka ta nie była reguła. Stąd trudności, na jakie w identyfikacji znaków pielgrzymich napotykają dzisiaj badacze.

Znaki pielgrzymie odnajdywane są wciąż na terenie miast niemal w całej Europie ${ }^{6}$. W Polsce takich znaków znaleziono jak dotąd stosunkowo niewiele - przede wszystkim na terenach dawnych miast hanzeatyckich ${ }^{7}$ w Gdańsku ${ }^{8}$, Szczecinie ${ }^{9}$, Kołobrzegu ${ }^{10}$, Wrocławiu ${ }^{11}$, Elblą-

5 T. Dunin-Wąsowicz, Średniowieczne znaki pielgraymie w Polsce. Komunikat, [w:] Peregrinationes. Pielgraymki w kulturze dawnej Europy, red. H. Manikowska, H. Zaremska, Warszawa 1995, s. 329.

6 M. Rębkowski, Pielgraymki miesžkańcón średnioniecznych miast poludniowego wybrzeża Battyku w śmietle znalęisk znakón patnicsych. Wstep do badań, Kwartalnik Kultury Materialnej, t. 52, 2004, s. 154.

G. Nawrolska, Dokead pielgryymowali Elblażanie w średniowieczu? Znaki pielgràymie śniadectwem pobożnych wedrówek, [w:] Archeologia et historia Urbana, Elblag 2004, s. 519.

8 A. Paner, H. Paner, Gdańszczanie na pielgrzymkowych szlakach w XIV i XV wieku, [w:] Gdańsk średniowieczny w swietle najnowsaych badan archeologicznych $i$ bistorycznych [Materiały z konferencji zorganizowanej z okazji tysiąclecia Gdańska (997-1997)], red. H. Paner, Gdańsk 1998, s. 167-183.

9 M. Rębkowski, M. Rulewicz, Cay mieszkeańcy Szczecina pielgraymowali w średnionieczu do Koloniz?, [w:] Instantia est mater doctrinae, red. E. Wilgocki, M. Dworczak, Szczecin 2001, s. 351-358.

${ }_{10}$ M. Rębkowski, Znaki pielgraymie, [w:] Archeologia średniowiecznego Kołobrzegu, t. 3, Kołobrzeg 1994, s. 223-227; M. Rębkowski, Ad sanctum Jacobum ultra montes. Prayyczynek do badan nad pielgraymkami mieszczan kotobrzeskich w średniowieczu, [w:] Civitas et Villa. Miasto i wieś w średniowiecznej Europie Środkowej, red. C. Buśko, J. Klapště, L. Leciejewicz, S. Moździoch, Wrocław-Praha 2002, s. 265-269.

11 T. Poklewski, Nowe znaleziska średnioniecznych znakón pielgraymich z Polski, Acta Archeologica Lodziensia 1968, s. 131-136; A. Żurek, Materialne ślady pielgryymek Ślazakón w średnio- 
$\mathrm{gu}^{12}$, ale też na Ostrowie Lednickim ${ }^{13}$ i w Gniewie ${ }^{14}$, chociaż należy się liczyć z tym, że liczba znanych zabytków w miarę postępowania badań archeologicznych będzie się stale powiększać. Jak można się spodziewać, również stan badań znaków pielgrzymich znalezionych na terytorium Polski jest stosunkowo ubogi. Dawniej sporadycznie poświęcano im osobne artykuły, obecnie powstaje ich coraz więcej, sa to jednak nadal przeważnie krótkie omówienia pojedynczych zabytków, bądź też niewielkich ich zespołów, o charakterze przyczynkarskim. Jeśli chodzi o znaleziska z terenu Gdańska, wymienić należy przede wszystkim artykuł Anny i Henryka Paner ${ }^{15}$ oraz artykuł Mariana Rębkowskiego ${ }^{16}$, w którym autor dokonał cennej próby podsumowania i usystematyzowania dotychczasowego stanu wiedzy na temat znaków pielgrzymich południowego wybrzeża Bałtyku, a także osadzenia znaków gdańskich w kontekście innych znalezisk $\mathrm{z}$ tego terenu.

Trzy ze znalezionych zabytków mają formę plakietek o kształcie kwadratu zwieńczonego trójkątem (Fot. 2a-b, 4a-b, 5a-b), z którego wierzchołków wyrastały niegdyś trzy krzyżyki (w żadnym ze znaków nie zachował się ich komplet). Plakietki te pierwotnie zaopatrzone też były w cztery uszka służące do mocowania. Kształt znaku i poszczególnych jego elementów podkreślony został, zarówno z jednej, jak i drugiej strony, przez cienki półwałek. Zaznacza on kontury plakietek, buduje i uczytelnia też formę krzyżyków i uszek. Awersy tych znaków zdobi przedstawienie figuralne, oddane w wypukłym reliefie, rewersy natomiast pokryte są w całości, również oddaną w reliefie, ukośną kratownica. Zarówno kompozycja przedstawień umieszczonych na tych trzech plakietkach, jak i ich detal, np. nimb krzyżowy otaczający głowę jednej z wyobrażonych tu postaci, są bardzo

wieczu. Komunikat, [w:] Peregrinationes, Warszawa 1995, s. 332-338; K. Wachowski, Plakietka pielgraymia (nr kat. 29), [w:] Ornamenta Silesiae. Tysiac lat rzemiosła artystycznego na Ślasku, red. M. Starzewska, Wrocław 2000, s. 72.

12 G. Nawrolska, Dokad pielgraymowali Elblażanie w średniowieczu, s. 517-527.

13 T. Dunin-Wasowicz, Średniowieczne znaki pielgraymie w Polsce, s. 328-331.

14 E. Choińska-Bochdan, Znaleziska o charakterze kultonym z Gniewa, Pomerania Antiqua, t. 13, 1998, s. 199-231.

15 A. Paner, H. Paner, Gdanszczanie na pielgraymkonych, s. 167-183.

16 M. Rębkowski, Pielgrasymki miesžkańcón średniowiecznych miast, s. 153-186. 
do siebie podobne, a w przypadku dwóch znaków (fot. 11, 12) - niemal identyczne. Przy ich produkcji korzystano zapewne z tego samego wzoru, chociaż z pewnością nie odlano ich z jednej formy, o czym świadczy szereg drobnych różnic zarówno na awersie jak i rewersie znaku, np. różne rozmiary kratownicy umieszczonej na rewersie. Przedstawienie figuralne tych plakietek wypełnia całe, tworzone przez powierzchnię znaku, pole. Wyobrażono tutaj dwie postaci. Z lewej strony widnieje postać siedzaca, prawą ręka, zgiętą w łokciu, podtrzymująca niewielki okragły przedmiot, lewą natomiast wyciagająca w kierunku drugiej, niższej postaci. Nad jej głową widoczne są trzy wrzecionowate elementy, które można identyfikować jako bardzo uproszczone przedstawienie pałkowej korony. Prawą stronę kompozycji zajmuje niższa postać stojąca. Jej głowa, otoczona nimbem krzyżowym, znajduje się nieco niżej niż głowa siedzącej postaci wyobrażonej z lewej strony. Lewa ręka tej postaci, zgięta w łokciu sprawia wrażenie opartej na biodrze, prawa jest niewidoczna. Ponadto na dwóch z plakietek (IP 1001 i 1342), u góry, nieco z prawej strony, nad głowa postaci z nimbem krzyżowym, wyobrażono sześcioramienna gwiazdę. Na trzecim znaku (IP 293) postaci otoczone są przez rośliny (roślinę?). Jest to gałąka pozbawiona liści, ale z owocami (lub bardzo uproszczonymi pakami kwiatów) w kształcie małych kuleczek. Forma reliefu zdobiącego powierzchnie znaków jest niezwykle uproszczona, wręcz prymitywna.

Trudno mówić o wyróżnieniu jakichkolwiek cech indywidualnych przedstawionych postaci, czy też wyróżnić stylistyczne, które mogłyby pomóc w bliższym datowaniu zabytków (lub nawet wzoru, według którego zostały wykonane). Ikonograficznie, można się domyślać, reliefy przedstawiaja tronująca Matkę Bożą w koronie i zapewne z jabłkiem w ręku. Obok zapewne stoi dziecięca postać Chrystusa. Można więc pokusić się o interpretacje przedstawień na tych trzech plakietkach jako wizerunku Marii - drugiej Ewy. Motyw roślinny na plakietce IP 293 nasuwa podobne skojarzenia (odniesienie do jabłoni?) lub też poszerza je (Madonna w krzewie różanym?). Niestety, modelunek całego przedstawienia jest tak uproszczony i technicznie niedokładny (nie wspominając już o niewielkich rozmiarach samego znaku i jego zniszczeniach), że trudno stwierdzić z pewnościa, jakiego rodzaju roślinę tu wyobrażono. Bardzo podobne plakietki z tronująca Matką Bożą znajdowano już wcześniej w Gdańsku na Wyspie Spichrzów (grupa 22 ta- 
kich znaków) i w kanale Raduni (2 egzemplarze ${ }^{17}$. Marian Rębkowski wyodrębnił jeszcze większą ich grupę ${ }^{18}$, wspominając o znaleziskach z Gniewu (jedna plakietka) ${ }^{19}$ oraz terenów północnych Niemiec: Greifswaldu i Lubeki. Oprócz tego wymienił też pojedyncze zabytki z Londynu, Bremy, Szwajcarii, Danii i Czech oraz większą ich grupę z Holandiii ${ }^{20}$. Znaki te charakteryzuje według niego na tyle bliskie podobieństwo, że z dużym prawdopodobieństwem założyć można, iż pochodza z tego samego centrum pielgrzymkowego o ponadregionalnym znaczeniu ${ }^{21}$. Ze względu jednak na dużą liczbę ośrodków kultu maryjnego w średniowieczu, niezwykle trudno określić jest dokładnie miejsce ich pochodzenia. Znaki maryjne wytwarzano przeważnie na terenie niemieckiego lub francuskiego obszaru kulturowego ${ }^{22}$. Marian Rębkowski podaje, że zachodnioeuropejscy badacze wprawdzie wskazują na Akwizgran, jako miejsce ich pochodzenia, jednak na razie twierdzenie to stanowi tylko hipotezę badawcza, która powinna ulec weryfikacji123.

17 Gdańscy badacze, Anna i Henryk Paner dokonali podziału znalezionych w tym mieście znaków na pięć podstawowych grup. Obiekty IP 1001 i 1342 należy łączyć z pierwsza wśród wydzielonych grup plakietek, natomiast plakietkę IP 293 można przyporządkować do trzeciej grupy wśród wydzielonych przez państwa Paner. (A. Paner, H. Paner, Gdańszcranie na pielgryymkonych szlakach w XIV $i$ XV wieku, [w:] Gdańsk średniowieczny w swietle najnowssych badan archeologicznych $i$ historycznych [Materiały z konferencji zorganizowanej z okazji tysiąclecia Gdańska (997-1997)], red. H. Paner, Gdańsk 1998, s. 179).

18 M. Rębkowski, Pielgraymmki mieszkańcón średniowiecznych miast poludniowego wybrzę̇a Battyku w swietle znalezisk żnaków patniczych. Wstęp do badań, Kwartalnik Kultury Materialnej, t. 52, 2004, s. 170-171.

19 A. Paner, H. Paner, Gdansz̨zanie na pielgrzymkonych szlakach, s. 178, 180-181; M. Rębkowski, Pielgraymki mies₹keńnców średniowiecznych miast południowego wybrzeża Battyku w świetle znalezisk znaków patnicsych. Wstep do badan, Kwartalnik Kultury Materialnej, t. 52, 2004, s. 169-171; Z opisu znaku z Gniewu, jaki zamieścili w swym artykule Anna i Henryk Paner, wynika jednak, że może prezentować on odmienny typ ikonograficzny. Wskazali też na jego podobieństwo do zabytku z Bremy i Lubeki. Być może więc wyodrębniona przez Rębkowskiego grupa zabytków nie jest tak jednorodna, na pewno zaś potrzebuje dalszych badań, o czym wspomina z resztą sam autor artykułu.

20 M. Rębkowski, Pielgraymki miesžkańcón średniowiecznych, s. 170-171.

21 Ibidem, s. 171.

22 A. Paner, H. Paner, Gdańszrzzanie na pielgrayymkonych szlakach, s. 178; Państwo Paner wskazują również na fakt, że w średniowieczu kult maryjny rozwijał się w różnych ośrodkach również w Prusach i na Pomorzu. Nie ma jednak jak dotąd dowodów na to, że wytwarzano w nich znaki pielgrzymie (A. Paner, H. Paner, Gdańszczzanie na pielgrzymkonych szlakach, s. 181-182).

23 M. Rębkowski, Pielgrazymki miesžkańcón średnioniecznych, s. 171. 
Pozostałe dwa znaki, niestety poważnie uszkodzone, przedstawiały kiedyś zapewne postaci świętego biskupa. Należą one do innego typu niż trzy omawiane powyżej, będące plakietkami, których powierzchnia posłużyła za tło dla ukazanego przedstawienia. W przypadku znaku IP 628 kontur plakietki jest zarazem konturem przedstawionej postaci (fot. 3a-b), zaś znak IP 129 jest figurka (fot. $1 \mathrm{a}-\mathrm{b}$ ).

Pierwszy znak IP 628 przedstawia postać stojąca (zachował się korpus postaci z jedną nogą), odzianą w paliusz. Postać tę ukośnie przecina półwałek - jest to fragment niezachowanego pastorału. Fałdy szaty sa drobne, modelowane miękko. Część z nich w partii brzucha formuje kolisty kształt w kształcie litery „u”, pozostałe opadaja ku dołowi w równoległych liniach.

Drugi znak IP 129, przedstawia postać siedząca, podobnie jak poprzednia - w stroju pontyfikalnym i z paliuszem. Głowa postaci nie zachowała się. W lewej ręce trzyma pastorał, prawą rękę unosi w górę w geście błogosławieństwa. Tutaj podobnie jak w przypadku pierwszej plakietki, fałdy szaty są drobne, miękko modelowane. Część z nich w partii brzucha formuje kolisty kształt w kształcie litery „u”, natomiast pozostałe opadają ku dołowi.

Przedstawienia biskupów na znakach pielgrzymich nie są rzadkościa. Wytwarzano je, m.in. w ośrodkach związanych z kultem św. Tomasza z Canterbury, ze św. Mikołajem z Bari, św. Tomaszem z Tours ${ }^{24}$, ale także w Maastricht, gdzie znajdował się grób i ośrodek kultu św. Serwacego. Pierwszy z omawianych tu znaków z przedstawieniami biskupów, na podstawie formalnego podobieństwa do rozpoznanego już znaku z Elblaga (ryc. 1), można ostrożnie zidentyfikować jako przedstawienie tego ostatniego świętego ${ }^{25}$. Według legendy św. Serwacy żył w IV wieku i był ostatnim biskupem limburskiego miasta Tongeren, skąd przeniósł siedzibę biskupią do Maastricht ${ }^{26}$. Jego kult zaczął rozwijać się w V w., swój szczytowy okres przeżywając w drugiej połowie XII stulecia. Najstarsze ze stopu cy-

${ }^{24}$ M. Rębkowski, Znaki pielgraymmie, [w:] Archeologia średnioniecænego Kołobrzegu, t. 3, Kołobrzeg 1994, s. 224.

${ }_{25}$ G. Nawrolska, Dokad pielgryymowali Elblażanie w średniowieczu? Znaki pielgraymmie swiadectwem pobozinych weedróneek, [w:] Archeologia et historia Urbana, Elblag 2004, s. 520.

${ }_{26}$ M.in.: Butler's Lives of the Saints [Ed. Rev. and supl. By Herbert Thurston SJ and Donald Attwater], t. 2, April, May, June, London, 1956, s. 297 (s.v. Servatius or Servais, Bishop 
ny i ołowiu znaki z wyobrażeniem św. Serwacego pochodzą właśnie z końca XII wieku. Wyobrażano na nich postać biskupa w stroju pontyfikalnym, w infule, z pastorałem w jednej dłoni i kluczem w drugiej. Na pewnej części plakietek biskup stoi na sylwetce smoka, któremu przebija gardło dolna częścia pastorału, na znak zwycięstwa nad herezją ariańską, którą zwalczał ${ }^{27}$. Do tego ostatniego typu ikonograficznego zalicza się również przedstawienie na znaku z Elblaga, datowanym na przełom XIV i XV wieku².

Z uwagi na poważne uszkodzenie o wiele trudniej o identyfikację postaci wyobrażonej na ostatnim ze znaków. Jedynymi wyróżniającymi ją cechami są bowiem pozycja siedząca, pastorał oraz gest błogosławieństwa. Brak dodatkowych atrybutów sprawia, że można byłoby ją zidentyfikować jedynie na podstawie analizy porównawczej z podobnymi znakami o wiadomej proweniencji, na razie jednak rozpoznanie jej ikonografii pozostaje kwestią otwartą.

Plakietka elbląska, do której podobny jest pierwszy ze znaków z postacia biskupa, datowana jest na przełom XIV i XV wieku ${ }^{29}$. Przy założeniu, że datowanie to jest prawidłowe można pokusić się o wyznaczenie czasu powstania znaku IP 628 na podobny okres. W przypadku figurki to podobny układ i miękki rysunek fałd szat pojawia się na znakach datowanych podobnie: na drugą połowę XIV i XV stulecie ${ }^{30}$. Ze względu jednak

of Tongres); W. Zaleski SDB, Święci na każdy dzień, Lódź 1982, s. 249-250 (s. v. św. Serwacy, biskup).

27 A. Paner, H. Paner, Gdańszczanie na pielgrzymkonych szlakach, s. 176; W Polsce odkryto dotąd trzy znaki z tym ostatnim przedstawieniem: w Kołobrzegu (M. Rębkowski, Znaki pielgraymie, s. 224-225), wspomniany już znak w Elblagu (G. Nawrolska, Dokad pielgraymowali Elblażanie, s. 520) i Gdańsku (A. Paner, H. Paner, Gdańsžczanie na pielgraymkeonych szlakach, s. 176.

${ }^{28}$ G. Nawrolska, Dokad pielgraymmowali Elblażanie, s. 520; Znak elbląski pierwotnie identyfikowany był jako przedstawienie św. Jerzego (G. Nawrolska, T. Nawrolski, Badania Starego Miasta w Elblagu w roku 1985, Kwartalnik Historii kultury Materialnej, t. 37, 1989, nr 2, s. 286 , ryc. $36-9$, s. 287$)$.

29 G. Nawrolska, T. Nawrolski, Badania Starego Miasta w Elblagu, ryc. 36-9, s. 287; G. Nawrolska, Dokad pielgraymowali Elblażanie, s. 520.

30 Por. np. plakietki z katalogu kolekcji znaków pielgrzymich Kunstgewerbemuseum i Museum für Byzantische Kunst, zwłaszcza znaki z nr kat. 12, 37 (H. Kühne, L. Lambacher, Das Zeichen am Hut im Mittelalter. Europäische Reisemarkierungen [Symposion In memoriam Kurt Koster (1912-1986)] und Katalog der Pilgerzeichen im Kunstgewerbemuseum und im 
na długa tradycję form, niewielkie rozmiary znaków i prymitywizm wykonania, nie są to podstawy, na których wyłącznie można byłoby opierać datowanie tego przedmiotu.

Omawiane znaki pielgrzymie wykonano ze stopów cynowoołowianych (IP 129, IP 293) i ołowianocynowych (IP 628, IP 1001, IP 1342) charakteryzujących się niskimi temperaturami topnienia w zakresie $180-280^{\circ} \mathrm{C}$ oraz dobra lejnością. Poza cyną i ołowiem w ich składzie wykryto również niewielką zawartość innych metali, jak miedź i żelazo (tab.1.), zanieczyszczeń przechodzacych do stopów w czasie wytopu metali z polimetalicznych rud, a niebędaccych celowym dodatkiem wpływającym znacząco na właściwości tworzywa. Są to typowe stopy przeznaczone do celów odlewniczych.

Tabela 1. Analiza składu stopowego wykonana metoda rentgenowskiej analizy fluorescencyjnej spektrometrem firmy Niton XLT 898BG ${ }^{31}$

\begin{tabular}{|c|c|c|c|c|c|c|}
\hline \multirow{2}{*}{ Lp. } & \multirow{2}{*}{ Nr inw. } & \multicolumn{5}{|c|}{ Skład stopowy (\%) } \\
\cline { 3 - 7 } & & Pb & Sn & Cu & Fe & Inne \\
\hline 1 & IP 129 & 0,5 & 99,0 & - & - & 0,5 \\
\hline 2 & IP 293 & 30,0 & 70,0 & - & - & - \\
\hline 3 & IP 628 & 62,0 & 36,0 & 0,2 & - & 1,8 \\
\hline 4 & IP 1001 & 77,0 & 20,0 & 0,9 & 0,8 & 1,3 \\
\hline 5 & IP 1342 & 54,0 & 45,0 & 0,2 & - & 0,8 \\
\hline
\end{tabular}

Znaki odlano w formach zamkniętych (muszlowych). Są to niecyzelowane, bardzo cienkie odlewy, których grubość waha się od 0,6 mm do 1,4 mm. Plakietki charakteryzuja się jeszcze jedną wspólną cechą - romboidalna siatka pokrywająca rewers. Zastosowanie siatki geometrycznej nie tyle wynikało z zamierzeń estetycznych, ile było technicznym rozwiązaniem. Przy prostej metodzie, jaka posługiwano się przy odlewaniu znaków pielgrzymich, forma posiadająca długie, często przecinające się rowki, lepiej rozprowadzała płynny metal, a to swoiste żebrowanie odlewu, ze stopu o tak niskiej wytrzymałości na zginanie, miało do pewnego stopnia zapo-

Museum für Byzantische Kunst der Staatlichen Museen zu Berlin, Frankfurt am Main-Berlin-Bern 2008, s. 282, 268].

31 Badania wykonano po usunięciu nawarstwień korozyjnych. 
biegać jego deformacjom. Dobór stopu, niewymagająca technika, niewielka ilość użytego materiału pozwalała na szybką i masowa produkcję.

Znaleziska zachowały się w złym stanie. Figurka jest zmiażdżona (fot. 1a-b), a znak IP 628 złamany (fot. 3 a-b). Cienkie odlewy uległy licznym deformacjom, zwłaszcza ich elementy wystające, jak krzyżyki i uszka. Niektórych brakuje, pozostały jedynie ślady ich odłamania. Występuja także ubytki. Tego rodzaju zniszczenia mechaniczne wynikają z niewielkiej wytrzymałości materiału. Relief stał się mało czytelny, gdyż pokryły go nawarstwienia pochodzące $\mathrm{z}$ warstwy gleby, w której zalegały obiekty do czasu ich wydobycia (fot. 7) oraz wskutek zmian korozyjnych prowadzacych do powstania osadów budujących grube, mniej lub bardziej jednolite warstwy (fot. 6). Cyna ma niższy od ołowiu potencjał standardowy redoks i w układzie omawianych stopów ona w pierwszej kolejności tworzy nawarstwienia korozyjne. Dominuje w nich tlenek cyny (IV) - kasyteryt - w postaci twardych, ciemnych narośli. Występuje także czarny tlenek cyny (II) - romarchit - oraz biały - uwodniony tlenek cyny (II) - hydroromarchit. Nawarstwienia korozyjne będą tworzyć związki ołowiu, np. węglan (VI) ołowiu (II) - cerusyt, siarczan (VI) ołowiu (II) - anglezyt i związki innych metali wchodzacych w skład stopu, jak żelazo.

Do oczyszczania archeologicznych obiektów cynowych i ołowianych J. M.Cronyn ${ }^{32}$, Bradley A. Rodgers ${ }^{33}$ oraz N. A. North ${ }^{34}$ proponuja stosowanie elektrolizy. Przy wyborze metody należy uwzględnić, iż związki ołowiu są trudno rozpuszczalne, ołów wrażliwy jest na kwasy organiczne, a niska twardość jego stopów z cyną ogranicza możliwość usuwanie nawarstwień na drodze mechanicznej. Metoda elektrolityczna jest trudna do kontrolowania, a więc ryzykowna. Niewielkie rozmiary znaków pielgrzymich stwarzaja natomiast problemy techniczne przy jej stosowaniu. Z tych powodów do usuwania nawarstwień i produktów korozji zastosowano metodę chemiczna. Kilkukrotnie przeprowadzono 20-minutowa kapiel statyczną w 10\%

32 J. M. Cronyn, The Elements of Archaeological Conservation, London-New York (2005), s. $207,212$.

33 B. A. Rodgers, The Archaeologist's Manual for Conservation. A Guide to Non-Toxic, Minimal Intervention Artifact Stabilization, New York 2004, s. 131.

34 C. Pearson, Conservation of Marine Archaeological Objects, 1998, s. 246. 
roztworze zasady sodowej, co pozwoliło na rozluźnienie nawarstwień. Sukcesywnie luźne warstwy usuwano pod strumieniem bieżącej wody. Oczyszczanie na drodze chemicznej pozwoliło na kontrolowane usuwanie depozytów glebowych i narostów produktów korozji, które czyniły formę nieczytelna, oraz umożliwiło pozostawienie warstw pasywacyjnych (patyny). Metoda ta nie dała zadawalających efektów jedynie w przypadku znaku IP 129. Jego powierzchnię punktowo doczyszczono metodą strumieniowościerna. Jako ścierniwo zastosowano korund o granulacji poniżej $0,15 \mathrm{~mm}$. Po zakończeniu procesu oczyszczania obiekty umyto woda destylowana, osuszono i odtłuszczono acetonem. Usunięto deformacje w ograniczonym stopniu, bez stwarzania ryzyka odłamania elementów reliefu. Złamany znak IP 628 sklejono żywica epoksydową Eurostac EP 2501 z utwardzaczem K Rapido 2503 w stosunku 100:33. Spoina wymagała wzmocnienia. Podklejono ja jedwabiem z włókna szklanego. Zastosowano podwójne powłokowe zabezpieczenie antykorozyjne. Najpierw na powierzchnię naniesiono 10\% roztwór żywicy akrylowej Paraloid B-44 (MMA/EA/nBMA w kompozycji procentowej 70:28:1) ${ }^{35} \mathrm{w}$ ksylenie, następnie wosk mikrokrystaliczny - Cosmolloid 80H rozpuszczony w benzynie lakowej.

Z niepozornymi znaleziskami, którymi są znaki pielgrzymie, wiążą się sprawy fundamentalne dla życia człowieka. Stanowią one namacalne świadectwo dawnej wiary i obyczajów religijnych. Sa dowodem na to, że pielgrzymowanie było ważną częścia życia ludzi w XIV i XV wieku. Moga również stanowić niezwykle cenne źródło wiedzy na temat dawnych dróg i miejsc pielgrzymkowych. Stosunkowo tani i dostępny materiał oraz prosta i szybka metoda ich wytwarzania wskazuja, że znaki pielgrzymie wykonywane były dla całej rzeszy pielgrzymujacych. Występowały w wielu typach, także z przeznaczeniem dla osób zamożniejszych, jak - być może - figurka odlana ze stopu wysokocynowego. Skuteczna metoda przywracania im wartości estetycznych jest stosowanie metody chemicznej na drodze kapieli w wodorotlenku sodu. Proces ten czasami należy wspomóc działaniem mechanicznym. Profilaktycznie należy je zabezpieczyć antykorozyjnie.

35 V. Horie, Materials for Conservation. Organic Consolidants, Adhesives and Coatings, Oxford 2010, s. 160. 


\section{Summary}

Pilgrim Signs.

Contribution from the Scope of the Material Culture and Conservation

The subject of the study are pilgrim signs obtained during archaeological excavations in the year 2008, on the Granary Island, Pszenna Street in Gdańsk. Extracted signs required conservation-restoration intervention leading to the restitution of aesthetic value and protection against corrosion processes.

These inconspicuous findings are related to fundamental for human life matters. They are the sign of faith and the proof that the pilgrimage was an important part of life for people in the fourteenth and fifteenth century. Relatively cheap and available materials (tin or lead alloys) as well as simple and quick method of their production (casting) indicate that pilgrim signs were being made for large quantity of pilgrims. There were many types of pilgrim signs, among them also the ones destined for wealthier people, like the figurine made of high tin alloy.

An effective method of restoring the aesthetic value of this kind of objects is to use chemical method of a sodium hydroxide bath. Sometimes the process should be supported by mechanical operations. Metal should be also preventively protected from corrosion. Using of acryl resin Paraloid B-44 and microcrystalline wax Cosmolloid $80 \mathrm{H}$ is suggested. 

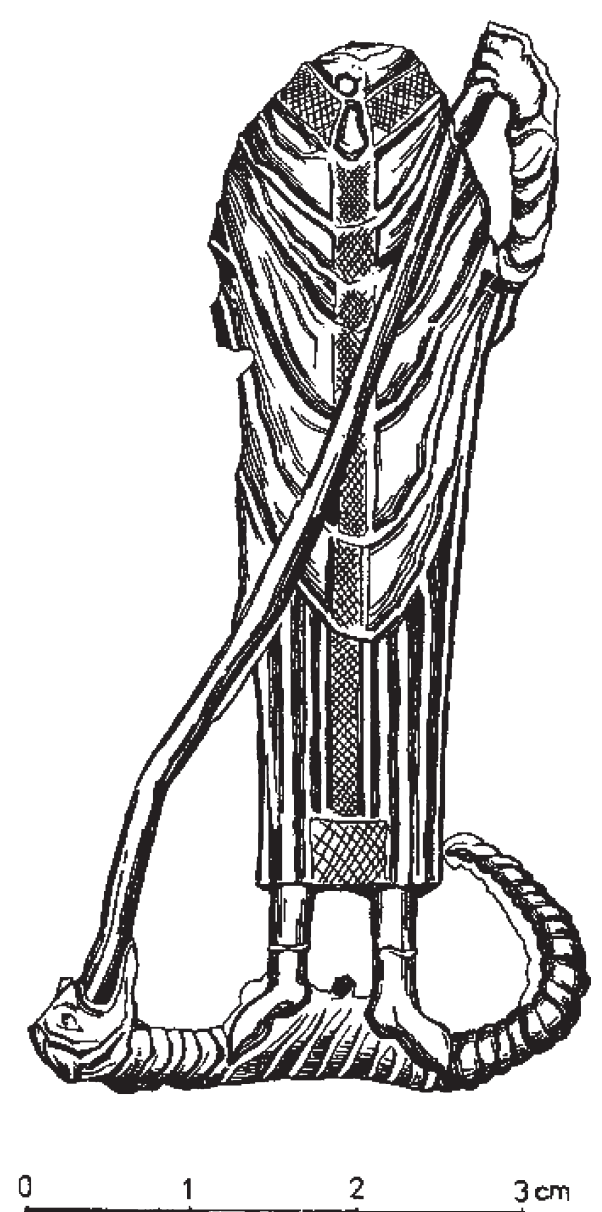

Ryc. 1. Elblag, Stare Miasto, ul. Kowalska 11, znak pielgrzymi - św. Serwacy, rys. B. Kiliński [wg. G. Nawrolska, Dokad pielgryymowali Elblażanie, s. 520] 

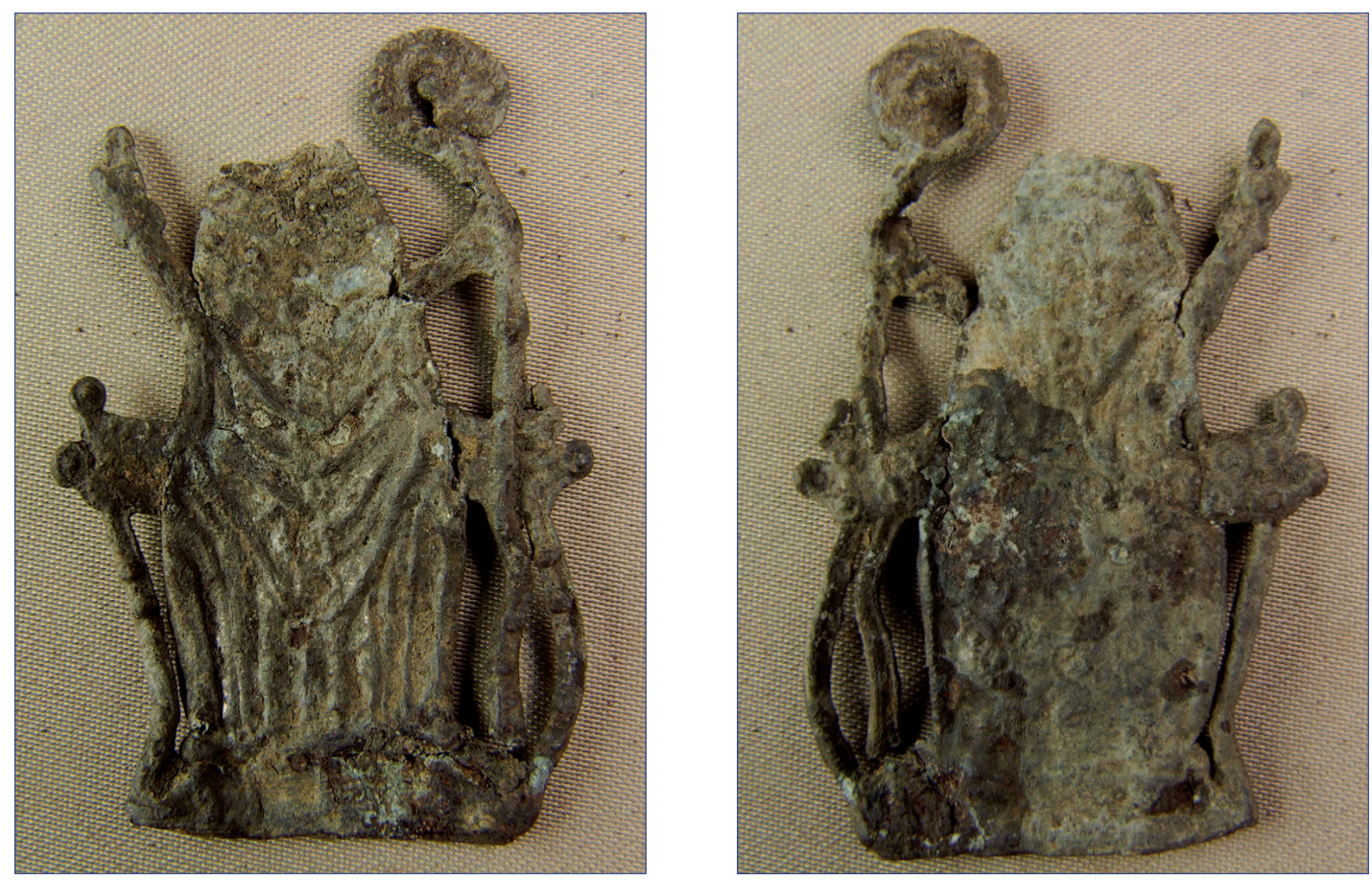

Fot. 1a, b. Znak pielgrzymi IP 129, awers i rewers, wymiary $54 \times 34 \mathrm{~mm}$. Stan przed konserwacja (fot. A. Tomaszewska-Szewczyk)
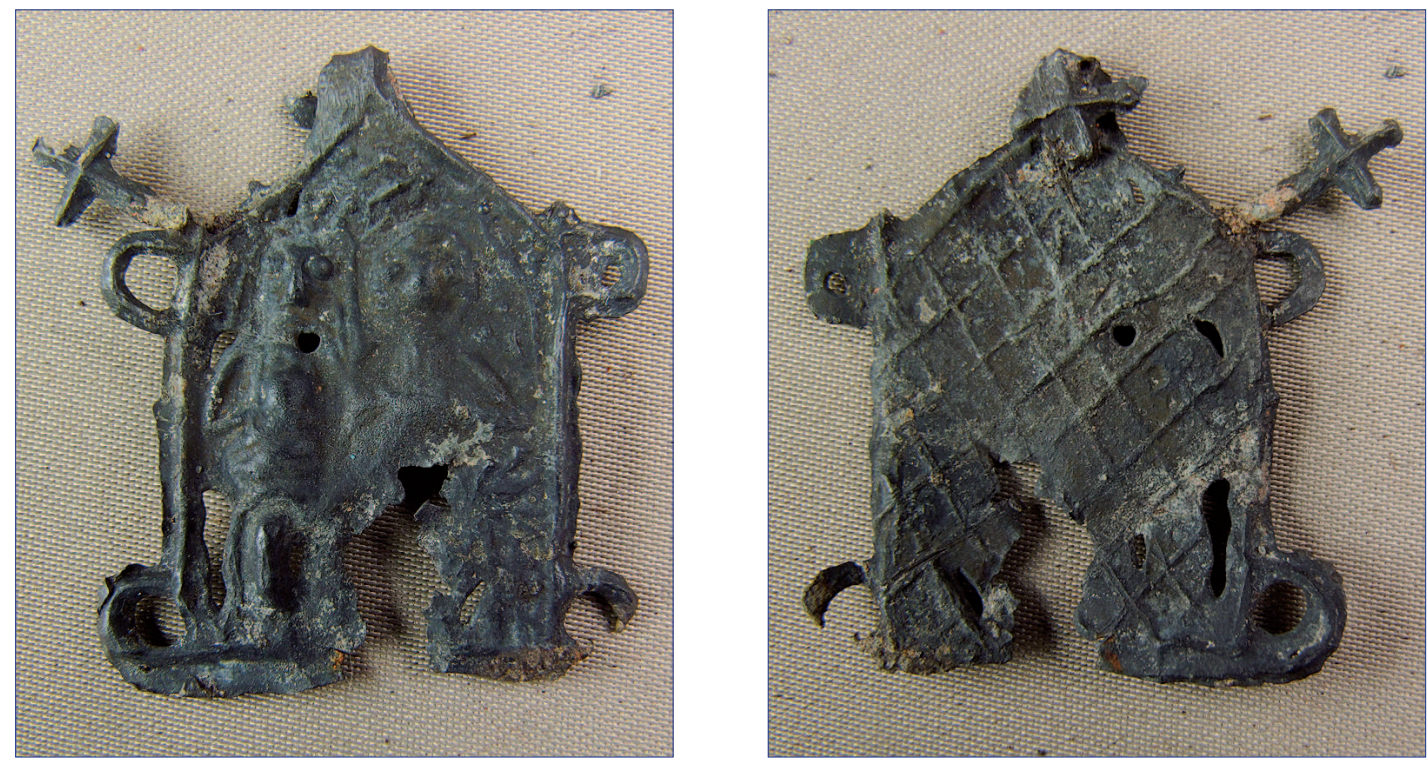

Fot. 2a, b. Znak pielgrzymi IP 293, awers i rewers, wymiary $36,5 \times 31,1 \mathrm{~mm}$. Stan przed konserwacja (fot. A. Tomaszewska-Szewczyk) 

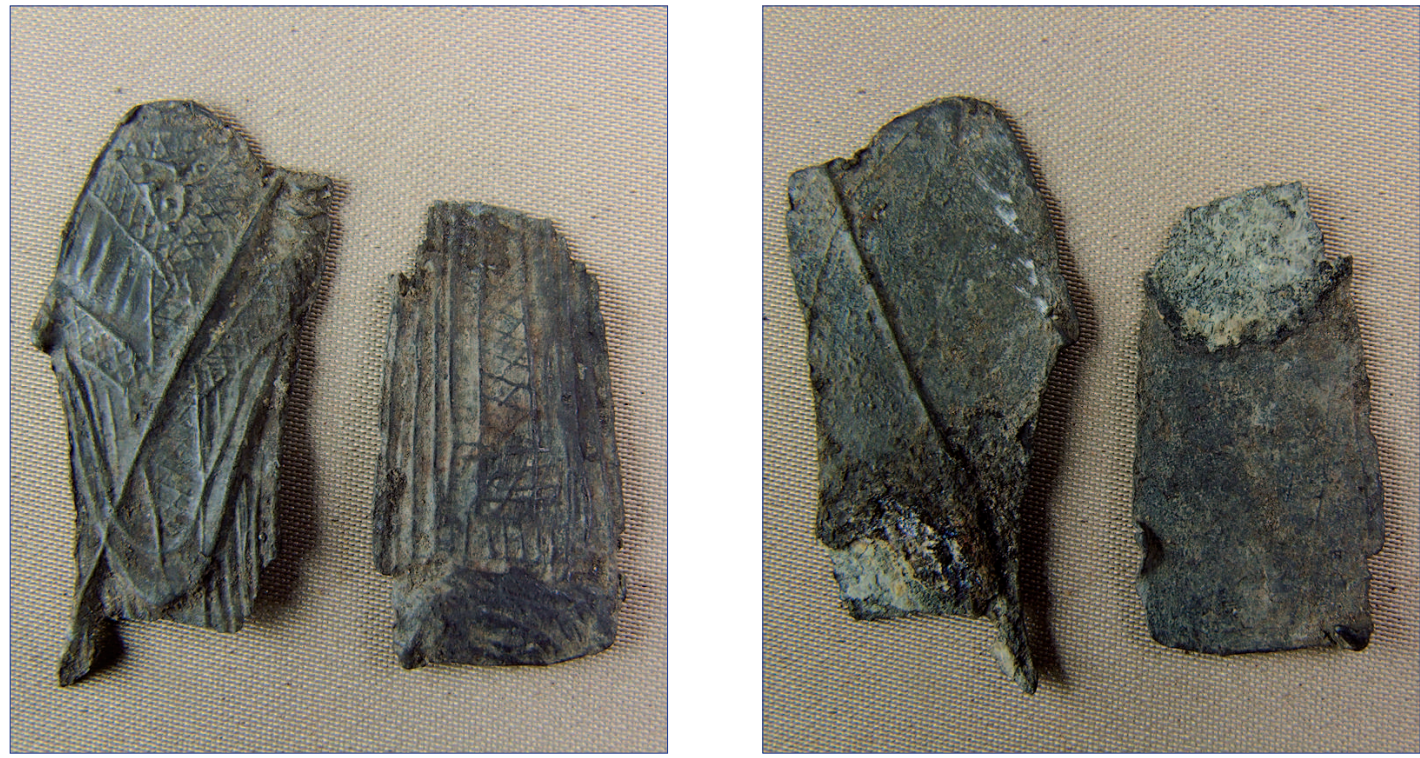

Fot. 3a, b. Znak pielgrzymi IP 628, awers i rewers, wymiary $40 \times 18,5 \mathrm{~mm} ; 30,4 \times 1,52 \mathrm{~mm}$. Stan przed konserwacja (fot. A. Tomaszewska-Szewczyk)
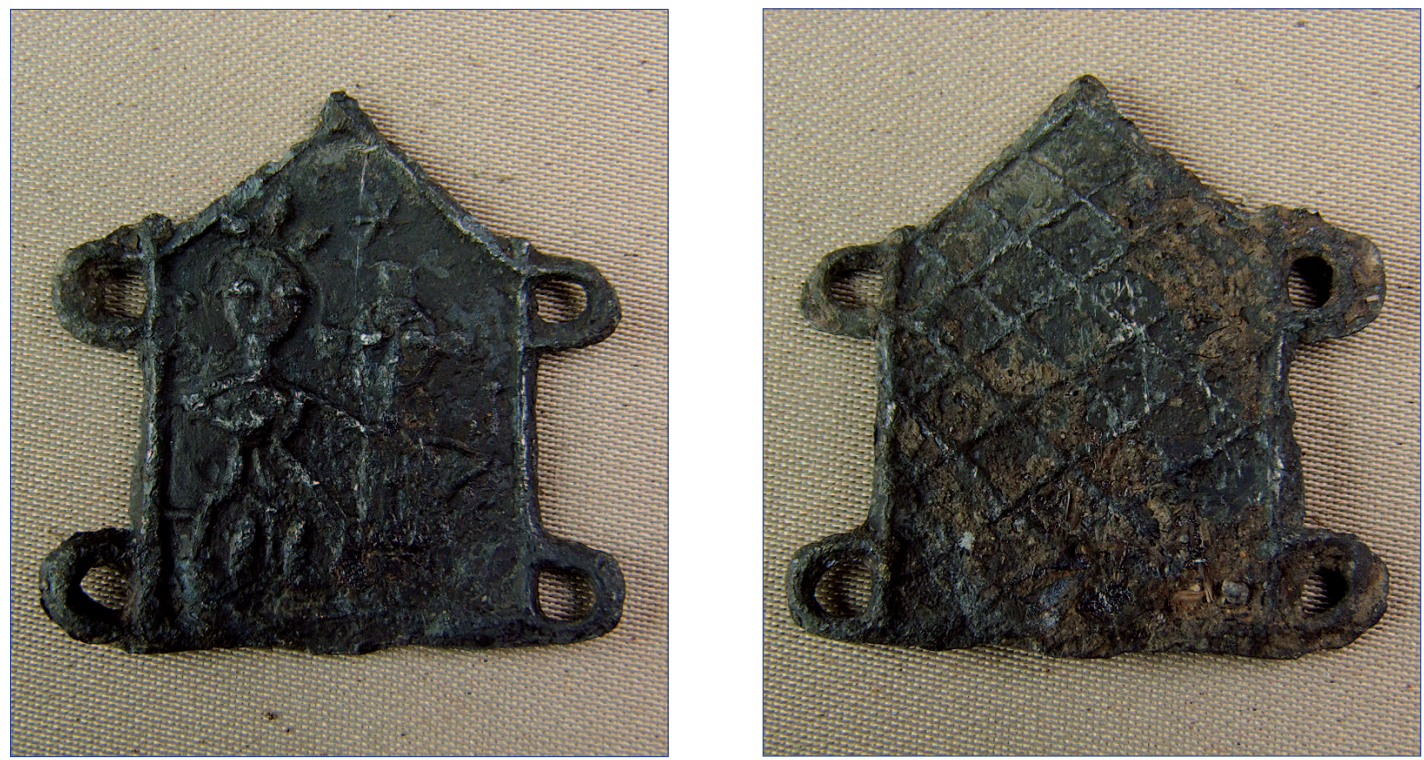

Fot. 4a, b. Znak pielgrzymi IP 1001, awers i rewers, wymiary $31 \times 31,6 \mathrm{~mm}$. Stan przed konserwacją (fot. A. Tomaszewska-Szewczyk) 

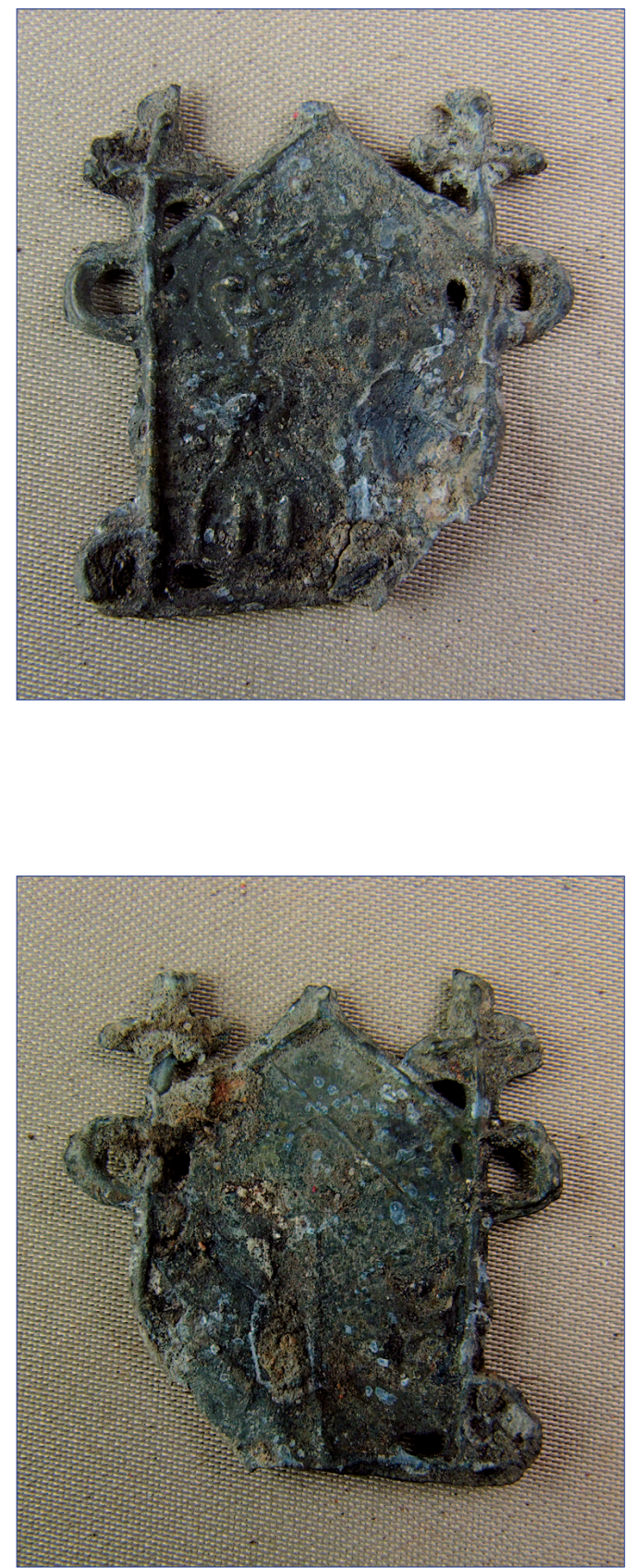

Fot. 5a, b. Znak pielgrzymi IP 1342, awers i rewers, wymiary $30,3 \times 30,8 \mathrm{~mm}$. Stan przed konserwacja (fot. A. TomaszewskaSzewczyk) 


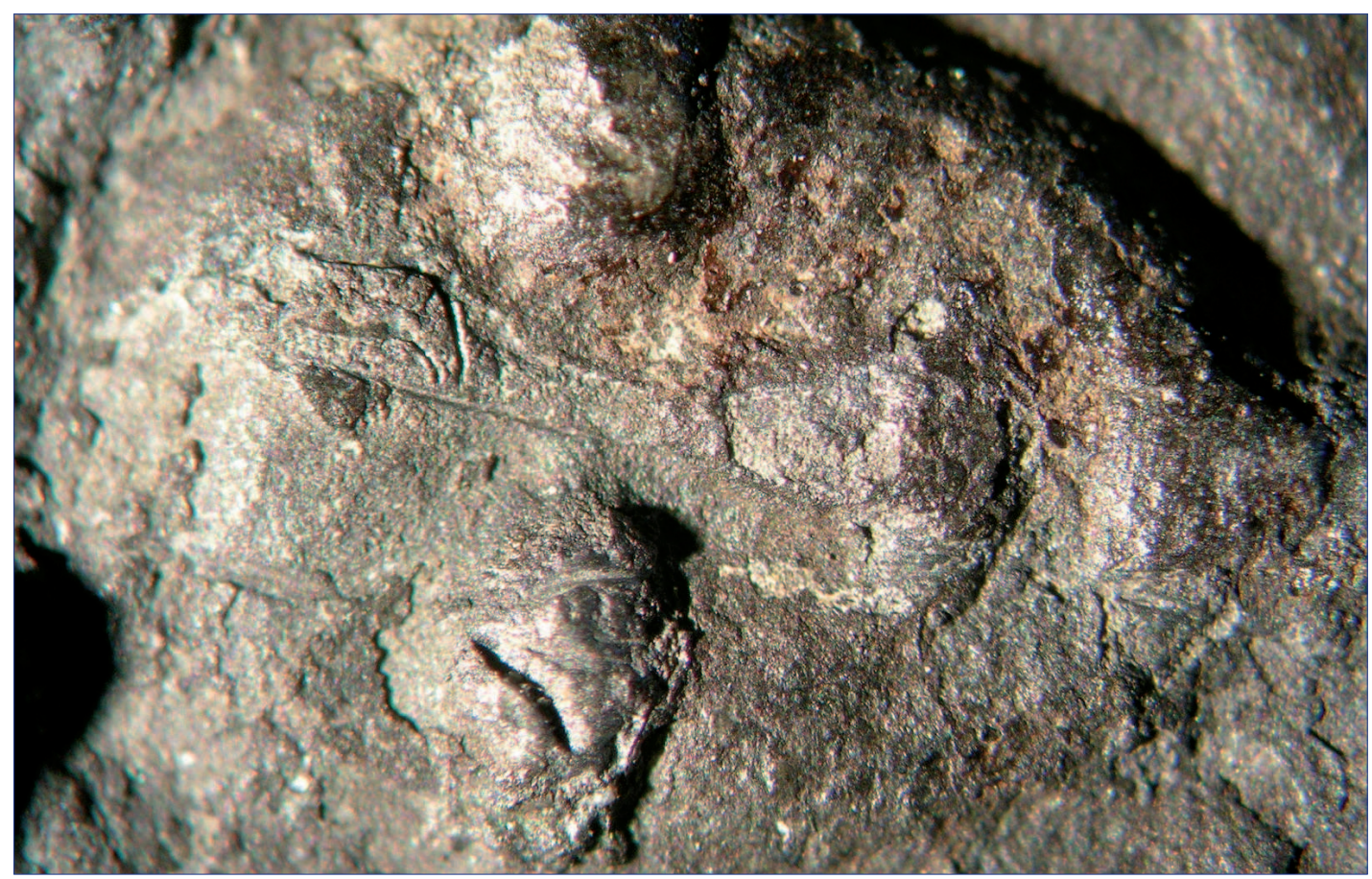

Fot. 6. Znak pielgrzymi IP 1001, awers, nawarstwienia korozyjne (fot. A. TomaszewskaSzewczyk)

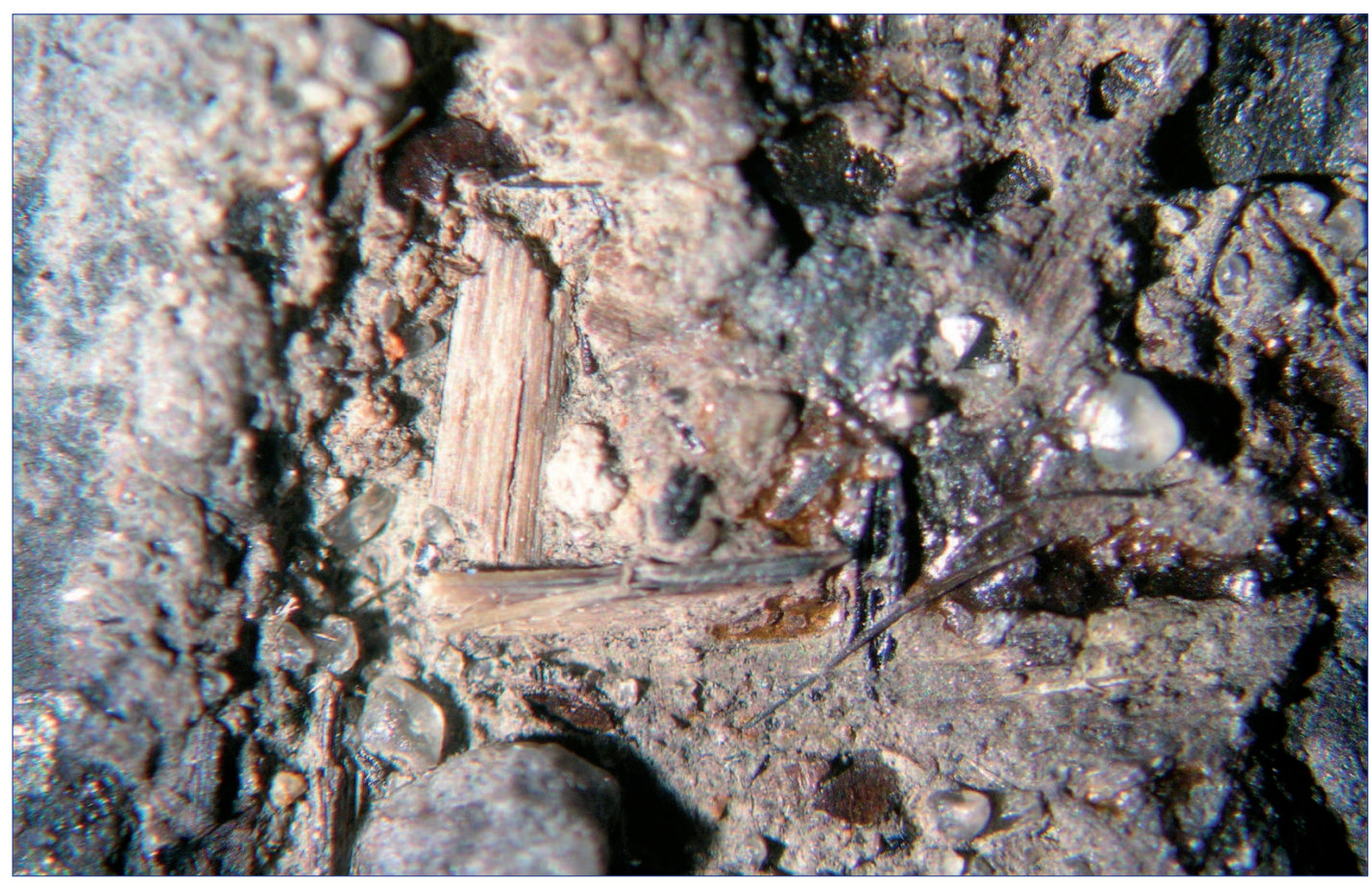

Fot. 7. Znak pielgrzymi IP 1001, rewers, depozyty organiczne i nieorganiczne: ziarna kwarcu, fragmenty drewna, mukek (fot. A. Tomaszewska-Szewczyk) 

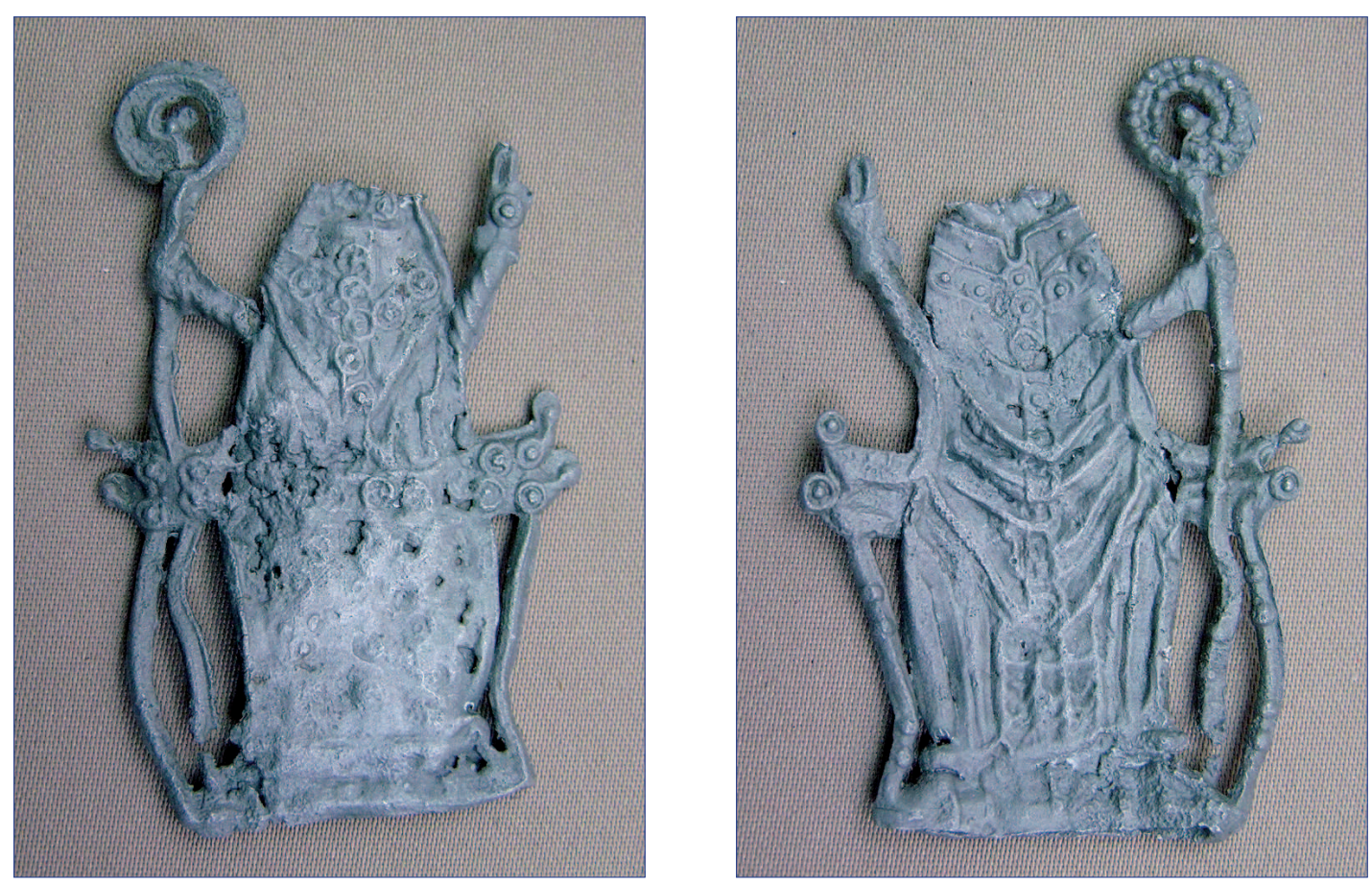

Fot. 8a, b. Znak pielgrzymi IP 129. Stan po konserwacji (fot. A. Tomaszewska-Szewczyk)

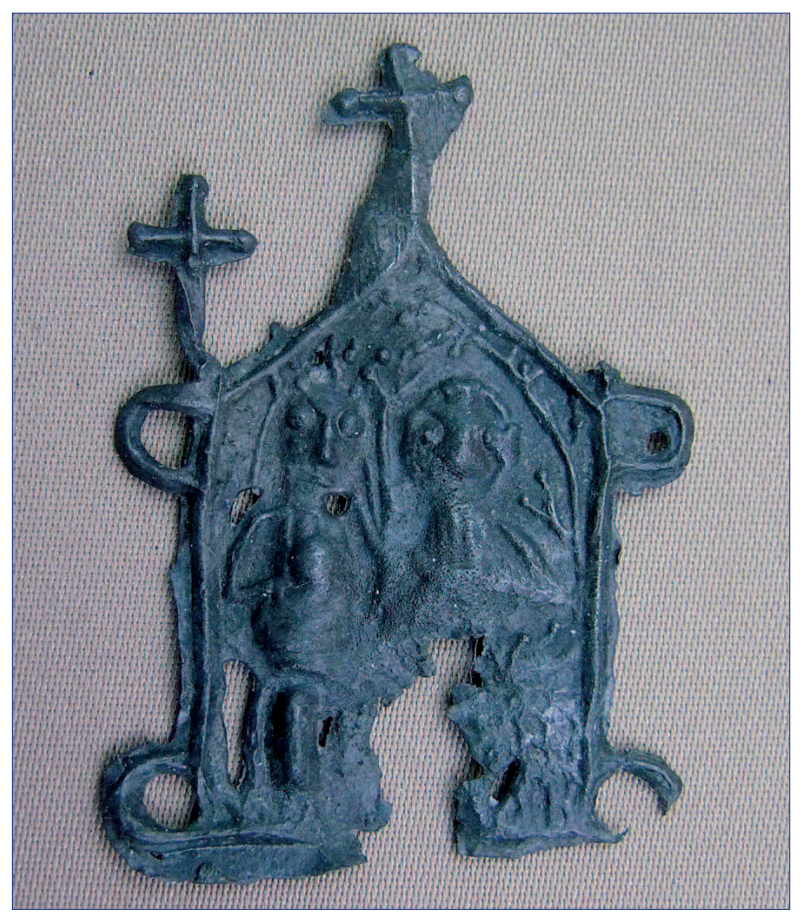

Fot. 9. Znak pielgrzymi IP 293. Stan po konserwacji (fot. A. Tomaszewska-Szewczyk) 


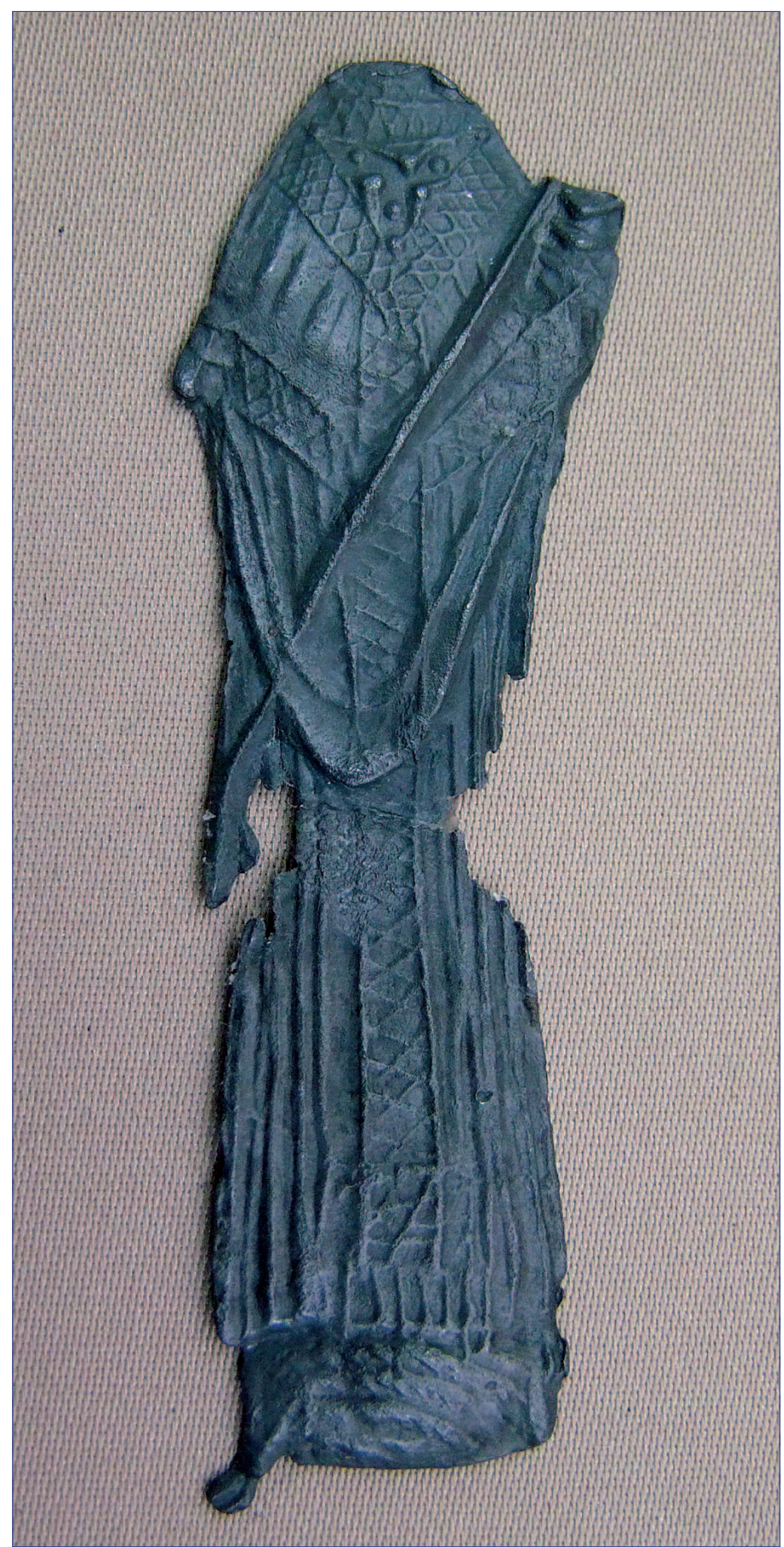

Fot. 10. Znak pielgrzymi IP 628. Stan po konserwacji (fot. A. Tomaszewska-Szewczyk) 


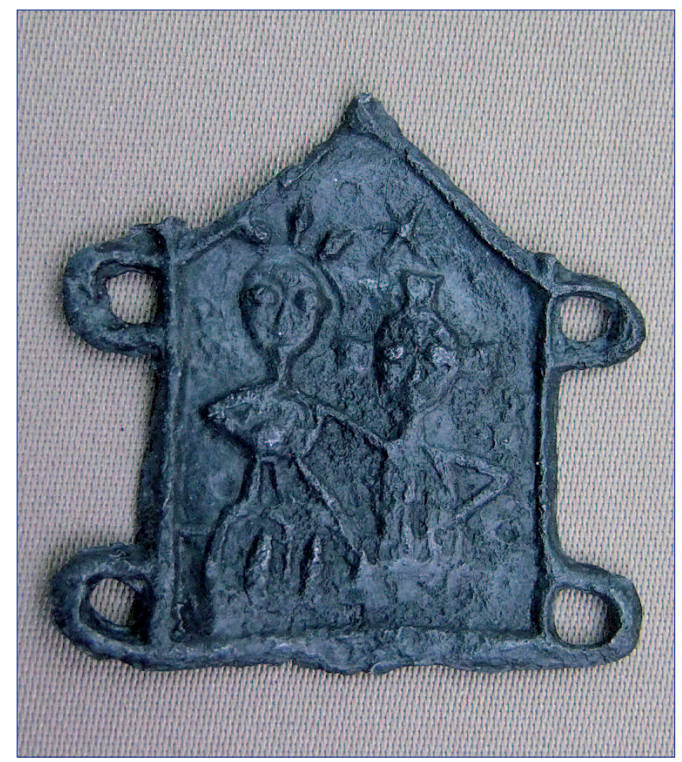

Fot. 11. Znak pielgrzymi IP 1001. Stan po konserwacji (fot. A. Tomaszewska-Szewczyk)

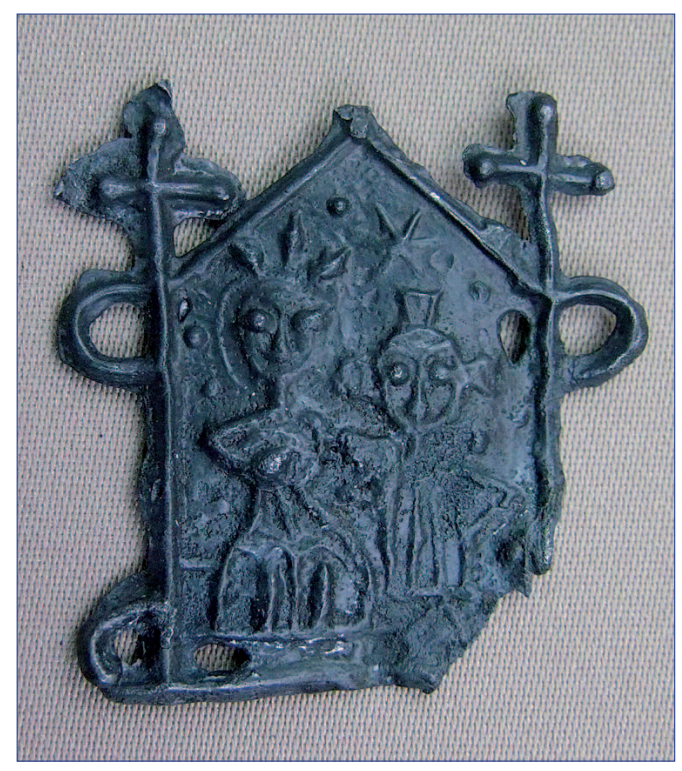

Fot. 12. Znak pielgrzymi IP 1342. Stan po konserwacji (fot. A. Tomaszewska-Szewczyk) 